\title{
Removal of Organic and Ammonium Nitrogen Pollutants in Swine Wastewater Using Electrochemical Advanced Oxidation
}

\author{
Kuo-Lin Huang ${ }^{1, *}$, Kuang-Chen Wei ${ }^{1}$, Mei-Hsia Chen ${ }^{2}$, Chen-Yao Ma ${ }^{3}$ \\ ${ }^{1}$ Department of Environmental Science and Engineering, National Pingtung University of Science and \\ Technology, Pingtung 91201, Taiwan (ROC) \\ ${ }^{2}$ Arounding-You Environmental Engineering Consultants Co. Ltd., Kaohsiung 830, Taiwan (R.O.C.) \\ ${ }^{3}$ Environmental Protection Bureau, Kaohsiung City Government, Kaohsiung 83347, Taiwan (R.O.C.) \\ *E-mail: huangkl@ mail.npust.edu.tw
}

doi: $1020964 / 2018.12 .32$

Received: 2 August 2018 / Accepted: 25 September 2018 / Published: 5 November 2018

\begin{abstract}
In this study, tests were performed to examine the effects of with/without chloride addition, electrolyte $\left(\mathrm{NaCl}\right.$ vs. $\mathrm{Na}_{2} \mathrm{SO}_{4}$ ), anode material (boron-doped diamond (BDD) vs. $\left.\mathrm{PbO}_{2}\right)$, current density $(0.10$ $\left.0.50 \mathrm{~A} / \mathrm{cm}^{2}\right)$, and anode area $\left(2-6 \mathrm{~cm}^{2}\right)$ on the electrochemical abatements of organic pollutants (in terms of total organic carbon (TOC) or chemical oxygen demand (COD)) and ammonia nitrogen in swine wastewater. The results showed that the TOC degradation was greater in the absence of chloride, but an opposite trend was observed for $\mathrm{NH}_{3}-\mathrm{N}$ electrochemical abatement. A similar phenomenon was also observed when replacing chloride with sulfate. In the presence of chloride, the $\mathrm{NH}_{3}-\mathrm{N}$ removal efficiencies were similar on $\mathrm{BDD}$ and $\mathrm{PbO}_{2}$, although the former anode was better for TOC degradation than the latter. The removal of both $\mathrm{COD}$ and $\mathrm{NH}_{3}-\mathrm{N}$ increased with increasing current density or anode area on BDD. During the electrolysis of the wastewater, nitrite was not detected in the presence of chloride except in the absence of chloride, in the presence of $\mathrm{Na}_{2} \mathrm{SO}_{4}$, or on $\mathrm{PbO}_{2}$ at 0.25 $\mathrm{A} / \mathrm{cm}^{2}$ and on BDD at $0.50 \mathrm{~A} / \mathrm{cm}^{2}$ in the presence of chloride. In the presence of chloride, the concentration of nitrate increased and then decreased with increases in electrolysis time for almost all the tested conditions. At $25^{\circ} \mathrm{C}$ and $0.25 \mathrm{~A} / \mathrm{cm}^{2}$, the pseudo-first-order rate constants for COD and $\mathrm{NH}_{3}-$ $\mathrm{N}$ removal were $7.05 \times 10^{-4}$ and $6.40 \times 10^{-4} 1 / \mathrm{s}$, respectively, while the general current efficiency and specific energy consumption were $15 \%$ and $9 \mathrm{kWh} / \mathrm{kg}-\mathrm{COD}$, respectively on BDD $\left(4 \mathrm{~cm}^{2}\right)$.
\end{abstract}

Keywords: swine wastewater; organic pollutants; ammonia nitrogen; electrochemical degradation; boron-doped diamond (BDD) electrode

\section{FULL TEXT}


(C) 2018 The Authors. Published by ESG (www.electrochemsci.org). This article is an open access article distributed under the terms and conditions of the Creative Commons Attribution license (http://creativecommons.org/licenses/by/4.0/). 